\title{
An evaluation of the expression profiles of salivary proteins lactoferrin and lysozyme and their association with caries experience and activity
}

\author{
Avaliação do padrão de expressão das proteínas salivares \\ lactoferrina e lisozima e sua associação com experiência e \\ atividade de cárie
}

\begin{abstract}
Purpose: Saliva contains both specific and non-specific protective factors of the immune system, such as antimicrobial proteins, which can inhibit the adhesion and viability of cariogenic microorganisms. The association between caries experience/activity and the electrophoretic profiles of salivary proteins lactoferrin and lysozyme was evaluated.

Methods: Eighty 12-year-old students from public schools in Londrina, PR, Brazil, were selected and divided into two groups: Group A - with decayed teeth and Group B - with caries-free teeth. The parent/guardian of each child signed a consent form and filled out a questionnaire regarding the oral and systemic health of his/her child. A clinical examination to diagnose the presence or absence of dental caries, by means of the DMFT index, was conducted. A total of $1 \mathrm{~mL}$ of saliva was collected for protein analysis using a polyacrylamide gel electrophoresis (SDS-PAGE).

Results: A total of $58.8 \%$ of the children were caries-inactive; in contrast, $63.3 \%$ showed caries experience. There was a slight association between lysozyme concentrations and DMFT. Lactoferrin was positively correlated with both DMFT and restored teeth.

Conclusion: The quantification of lactoferrin and lysozyme enabled an assessment of possible associations with caries status, thus improving the understanding of the biological and etiological aspects of caries.
\end{abstract}

Key words: Lysozyme; lactoferrin; dental caries; saliva; electrophoresis, polyacrylamide gel

\section{Resumo}

Objetivo: A saliva contém fatores de defesa adquiridos e não adquiridos, como proteínas antimicrobianas capazes de inibir a aderência e a viabilidade dos microrganismos cariogênicos. Avaliou-se a associação entre a experiência/atividade de cárie e o perfil eletroforético das proteínas salivares lactoferrina e lisozima.

Metodologia: Oitenta escolares aos 12 anos de idade da Rede Estadual de Ensino de Londrina, PR, Brasil, foram divididos em dois grupos: Grupo A - com cárie e Grupo B - sem cárie. Os responsáveis legais assinaram um termo de consentimento informado, e responderam um questionário sobre a saúde bucal e sistêmica das crianças. Foi realizado exame clínico, para diagnosticar a presença ou ausência de cárie através do Índice CPO-D e coletado $1 \mathrm{~mL}$ de saliva para análise das proteínas por meio da eletroforese em gel de poliacrilamida (SDS-PAGE).

Resultados: Observou-se que 58,8\% das crianças eram cárie-inativas, apesar de 63,3\% possuírem experiência de cárie. Houve uma tendência de associação entre a concentração de lisozima com o CPO-D. A proteína lactoferrina correlacionou-se positivamente com CPO-D e dentes restaurados.

Conclusão: A quantificação destas proteínas permitiu observar possível associação com a cárie, favorecendo uma melhor compreensão do aspecto biológico e etiológico da doença.

Palavras-chave: Lisozima; lactoferrina; cárie dentária; saliva; eletroforese em gel de poliacrilamida

\author{
Klíssia Romero Felizardo a \\ Rafael Braga Gonçalves ' \\ Waleska Dias Schwarcz ${ }^{c}$ \\ Regina Célia Poli-Frederico d \\ Sandra Mara Maciel d,e \\ Flaviana Bombarda de Andrade ${ }^{f}$
}

\begin{abstract}
a Master's course in Preventive and Restorative Dentistry, North Paraná University (UNOPAR), Londrina, PR, Brazil

b Biochemistry Department, Biomedical Institute, Federal University of Rio de Janeiro State (UNIRIO), Rio de Janeiro, RJ, Brazil

cBiochemistry Institute, Biological Structural Program, Federal University of Rio de Janeiro, Rio de Janeiro, RJ, Brazil

¿Dental School, North Paraná University (UNOPAR), Londrina, PR, Brazil

e Dental School, Maringá State University, Maringá, PR, Brazil

† Bauru School of Dentistry, University of São Paulo, Bauru, SP, Brasil
\end{abstract}

Correspondence:

Flaviana Bombarda de Andrade

R. Henrique Savi 14-44, ap. 601

Bairro Cidade Universitária

Bauru, SP - Brasil

17012-205

E-mail: flaviana@fob.usp.br

flavianabombarda@hotmail.com

Received: January 28, 2010

Accepted: October 1, 2010

Conflict of Interest Statement: The authors state that there are no financial and personal conflicts of interest that could have inappropriately influenced their work.

Copyright: (c) 2010 Felizardo et al.; licensee EDIPUCRS. This is an Open Access article distributed under the terms of the Creative Commons AttributionNoncommercial-No Derivative Works 3.0 Unported License. 


\section{Introduction}

The surfaces in the oral cavity are constantly colonized by microorganisms. This microbiota is influenced by both specific (antibodies) and non-specific (innate) components such as antimicrobial proteins lysozyme (LZ) and lactoferrin (LF) associated with the secretory immunologic system. Most of these proteins can inhibit the metabolism, adherence and cariogenic viability of microorganisms in vitro (1-3). The clinical functions of lysozyme and lactoferrin in the oral cavity are still not clear. However, they appear to have an important role in controlling microbial overgrowth, reducing the number of bacteria in the dental biofilm, decreasing colonization and modifying bacterial metabolism. They contribute to the installation and maintenance of a stable ecosystem, in which harmless species outnumber potentially dangerous species to provide microbial protection. The antimicrobial systems in human saliva are involved in the first line of defense in the oral cavity $(2,4,5)$.

Dental caries is a multifactorial disease, of which salivary parameters represent only a fraction of all contributing factors. A diminished flow rate is a risk factor for caries development, and each of the salivary constituents contributes to the overall capacity of salivary function. However, there are significant difficulties associated with the identification of specific salivary parameters as disease risk factors $(1,2,6)$.

Streptococcus mutans, a Gram-positive bacterium, is an oral pathogen considered to be the principal etiologic agent behind dental caries (7). Some authors have observed the antimicrobial effects of lactoferrin against $S$. mutans in vitro $(4,8,9)$. The capacity of lactoferrin to chelate available iron and inhibit $S$. mutans adhesion plays a key role in protecting the human oral cavity from bacterial pathogenicity (5).

Scientific reports indicate increased levels of caries experience when there is reduced salivary flow $(6,10-13)$, which reinforces the interest in elucidating the role of salivary components in caries development. Mass et al. (6) found an association between low lysozyme levels and decreased numbers of $S$. mutans and lactobacilli. Also, the presence of lactoferrin seems to be associated with dental caries. Such findings contribute to an increased knowledge of the etiologic aspects of this disease, according to Sikorska, Mielnik-Blaszczak, Kapec (11), Azevedo et al. (12) and Vitorino (13).

SDS-PAGE is a unidimensional method used to analyze the molecular weights and charges of proteins by separating the proteins into bands, thereby making them visible. The most common use of gel electrophoresis is the qualitative analysis of the complex mixtures of proteins (14). Schwartz et al. (15) proposed polyacrylamide gel electrophoresis (SDS-PAGE) as an adequate method to evaluate protein content in the human saliva.

The purpose of this study was to evaluate the expression profiles of the salivary proteins lysozyme and lactoferrin using the SDS-PAGE method and to correlate these profiles with dental caries experiences in 12-year-old children using the DMFT (decayed, missing or filled teeth) index.

\section{Methodology}

An observational cross-section study was designed and approved by the Research Ethical Committees of North of Paraná University - UNOPAR (Protocol number PP212/08). The study population was comprised of students of both genders who attended a public school in Londrina, PR, Brazil. This school was chosen because of its location in a social risk area. The criteria of the selected students were as follows: 1) 12 years old; 2) no other systemic diseases; and 3) no use of medication that could modify salivary parameters (e.g., antibiotics or anti-inflammatories) for at least 30 days prior to the study. Only children whose parents (or legal guardians) had signed an informed consent form were enrolled in the study. All participants lived in Londrina, PR, Brazil, which is known for its high concentration of fluoride in the public water supply (approximately $0.77 \mathrm{ppm}$ ).

The mothers of the selected students completed the questionnaires, providing personal data, medical and dental histories (including medicament use) and oral hygiene habits.

The oral health of each child was evaluated using a unique calibrated examiner and a second person to help record the data. The exams were performed at the school with the aid of artificial light and plane mirrors. Caries experience and severity were observed via the World Health Organization (WHO) (16) criteria, using the DMFT (decayed, missed and filled teeth) index. In some doubtful cases, an explorer with a round tip was used to facilitate the diagnosis. Subsequently, oral hygiene instructions were provided and cleanings were performed on the children.

A pilot study with 20 children was previously conducted to assess the validity of the methodology and the examiners' level of calibration. The kappa inter- and intra-examiner values were 1.0 and 0.857 , respectively.

For caries experience analysis, the students were placed into two groups: Group 1 - students with dental caries $(\mathrm{CPO}-\mathrm{D} \geq 1)$ and Group 2 - students without dental caries $(\mathrm{CPO}-\mathrm{D}=0)$. For the caries activity analysis, the students were divided into Group A, which included caries-active subjects (possessing decayed teeth and restored teeth with caries) and Group B, which included caries-inactive subjects (with healthy and restored teeth).

Immediately following lunch, each student brushed his/her teeth. Two hours later, the students chewed on a Parafilm "M" pellicle (Laboratory Film; American National Can. Chicago, IL, USA) of $3.0 \times 3.0 \mathrm{~cm}$ for one minute, without swallowing, to stimulate salivation. One milliliter of saliva was collected from each student using disposable syringes. The samples were identified and stored in a thermal box, submersed in dry ice and taken to UNOPAR's laboratory as quickly as possible to avoid protein degradation due to proliferating microorganisms. 
After weighing, the salivary samples were placed in a frozen centrifuge (Mikro $22 \mathrm{R} /$ Hettich Zentrifugen) for 10 minutes at $4{ }^{\circ} \mathrm{C}$ and $10,000 \mathrm{rpm}$ to eliminate cellular debris. The samples were stored at $-20^{\circ} \mathrm{C}$, and $100 \mu \mathrm{L}$ of each were freeze-dried for 48 hours (Liofilizador L 101/LIOBRAS) to concentrate the salivary proteins. The freeze-dried samples were resuspended in $30 \mu \mathrm{L}$ of TRIS- $\mathrm{HCl} 50 \mathrm{mM}(\mathrm{pH} 7.5)$ buffer and added to $50 \mu \mathrm{L}$ of denaturizing solution SDS/DDT/ bromophenol blue $(50 \mathrm{mM})$. Finally, they were boiled in a water bath for one minute and submitted to polyacrylamide gel electrophoresis.

Commercial lactoferrin and lysozyme pattern solutions were prepared and then inserted into the polyacrylamide gel to serve as controls. Fifteen microliters of bovine lactoferrin (Life Extension, Ft. Lauderdale, FL, USA) was added to $60 \mu \mathrm{L}$ of buffer $(62,5 \mathrm{mM}$ TRIS HCl, $20 \%$ glycerol, $2 \%$ SDS, 5\% $\beta$-mercaptoethanol $-\mathrm{pH} 6.8$ and bromofenol), with a final concentration of $1.5 \mathrm{mg} / \mathrm{mL}$. Next, $100 \mu \mathrm{L}$ of lysozyme (Sigma-Aldrich, Switzerland) was added to $100 \mu \mathrm{L}$ of the same buffer, to reach a final concentration of $80 \mathrm{mg} / \mathrm{mL}$.

Polyacrylamide gel electrophoresis (SDS-PAGE) was conducted according to Laemmli (17) with a $15 \%$ bisacrylamide concentration using the vertical system BioRad/Miniprotean 3 cell 600 VDC/13W/USA. The molecular weight pattern Prestained SDS-PAGE (BioRad, USA) was applied to the first slot, followed by samples of saliva from caries-active students (second, third and fourth slots $-20 \mu \mathrm{L}$ ) and samples of saliva from caries-inactive students (fifth, sixth and seventh slots $-20 \mu \mathrm{L}$ ). The last two slots were filled with LZ and LF pattern solutions.

The electrophoresis was conducted using an amperage of $23 \mathrm{~mA}$. The gel was stained with Coomassie Brilliant Blue dye for 24 hours. The gel was washed in distilled water and placed into a discoloring solution to achieve complete discoloration. The gels were identified and stored in distilled water under refrigeration, to be digitized and analyzed using software L-PIX 1D-L340 (Loccus Biotecnologia, Brazil). The bands produced during the electrophoresis enabled the quantification of the proteins in each sample, which helped to obtain their salivary concentrations.

The Statistical Package for Social Sciences 15.0 (SPSS, London, UK) was used to calculate the frequency of the population data and to correlate the analyzed factors. Pearson and Spearman correlation tests were performed, as well as Kruskall-Wallis and Mann-Whitney variance tests, to verify differences between the groups with or without caries and to determine the salivary protein concentrations.

\section{Results}

The final sample in this study included 80 students. Of the 90 12-year-old students attending the school, 10 did not provide consent forms, representing an answer rate of $88.8 \%$. None of these students showed any systemic disease or was using any of the aforementioned medications.
An evaluation of oral conditions, by means of the dental caries experience, was carried out using the DMFT index according to WHO criteria. The DMFT average of this population was $2.09 ; 63.3 \%$ of students showed caries experience, whereas $58.8 \%$ were caries-inactive (Table 1 ).

Table 1. Distribution of students according to their dental caries experiences.

\begin{tabular}{lcc}
\hline & Caries & Frequency (\%) \\
\hline Caries experience & Yes (group 1) & $53(63.3)$ \\
& No (group 2) & $27(33.8)$ \\
Caries activity & Active (group A) & $33(41.3)$ \\
& Inactive (group B) & $47(58.8)$ \\
\hline
\end{tabular}

A total of $28(35 \%)$ boys and $52(65 \%)$ girls were involved in the study. To evaluate the caries experience related to gender, students with a DMFT $=0$ were compared with those with a DMFT $\geq 1$. The Mann-Whitney test did not detect a relationship between caries experience and student gender $(P=0.399)$. The DMFT averages were 2.43 for males and 1.9 for female students, and the filled component was the most frequent.

Variance tests were used to compare the groups (with or without caries) in terms of the presence and concentration of salivary proteins. Lactoferrin was absent (or not detected) in the saliva of 44 volunteers and was present in 36 participants. The Mann-Whitney test did not reveal a statistically significant relationship between salivary LF and the DMFT index ( $P=0.057)$, although this $P$-value was close to our cut-off value. There was no relationship between LF and decayed teeth $(P=0.169)$ nor between LF and decayed and filled (restored) teeth $(P=0.269)$. However, significant results were found between protein presence and the number of restored teeth $(P=0.016)$.

Lysozyme (LZ) was present in all of the participants in various concentrations. Twenty-four students showed salivary LZ concentrations below $81.55 \mathrm{mg} / \mathrm{mL}, 28$ students showed concentrations between $81.56 \mathrm{mg} / \mathrm{mL}$ and $91.55 \mathrm{mg} / \mathrm{mL}$ and 28 students showed concentrations over $91.56 \mathrm{mg} / \mathrm{mL}$ (Table 2).

Table 2. Distribution of students in relation to lysozyme concentration.

\begin{tabular}{ccc}
\hline LZ & Concentration & Frequency (\%) \\
\hline $\mathrm{LZ}$ & $<81.55 \mathrm{mg} / \mathrm{mL}$ & $24(30.0)$ \\
& $81.56-91.55 \mathrm{mg} / \mathrm{mL}$ & $28(35.0)$ \\
& $>91.56 \mathrm{mg} / \mathrm{mL}$ & $28(35.0)$ \\
Total & & $80(100.0)$ \\
\hline
\end{tabular}

The Kruskall-Wallis test did not detect a relationship between $\mathrm{LZ}$ concentrations and the DMFT index $(P=0.382)$ or between LZ and the index components of decayed teeth $(P=0.324)$, restored and decayed teeth $(P=0.395)$ or teeth with only restorations $(P=0.594)$. 
Table 3. Mean values of the DMFT index and its components distributed by LF presence and LZ concentration.

\begin{tabular}{lcccc}
\hline $\begin{array}{c}\text { Proteins } \\
\text { (Concentration) }\end{array}$ & DMFT & Carious teeth & $\begin{array}{c}\text { Carious and } \\
\text { restored teeth }\end{array}$ & Restored teeth \\
\hline $\begin{array}{l}\text { LF presence } \\
\text { Yes }\end{array}$ & 2.75 & 0.83 & 0.03 & $1.75^{*}$ \\
$\quad$ No & 1.55 & 0.59 & 0.00 & 0.73 \\
LZ concentration & & & & \\
$<81.55 \mathrm{mg} / \mathrm{mL}$ & 2.79 & 0.96 & 0.00 & 1.58 \\
$\quad 81.56-91.55 \mathrm{mg} / \mathrm{mL}$ & 1.96 & 0.64 & 0.00 & 1.18 \\
$>91.56 \mathrm{mg} / \mathrm{mL}$ & 1.61 & 0.54 & 0.04 & 0.86 \\
\hline
\end{tabular}

* $P=0.016$; LF - Lactoferrin; LZ - Lysozyme

\begin{tabular}{ccccc}
\hline Variable & DMFT & Carious teeth & $\begin{array}{c}\text { Carious and } \\
\text { restored teeth }\end{array}$ & Restored teeth \\
\hline LF & $0.245\left(^{*}\right)$ & 0.105 & 0.155 & $0.297\left(^{* *}\right)$ \\
LZ & -0.115 & -0.81 & 0.066 & -0.145 \\
\hline
\end{tabular}

LF - Lactoferrin, LZ- Lysozyme

(**) Significant correlation at 0.01

$\left(^{*}\right)$ Significant correlation at 0.05
Pearson correlation test (for the numerical variable) and Spearman's correlation test (for the categorical variable) were employed to confirm a possible correlation between the data. There was a positive correlation between LF and the DMFT index, as well as between LF and restored teeth (Table 4).

\section{Discussion}

Lysozyme, lactoferrin, lactoperoxidase, agglutinins, mucin, histatin, cystatin and immunoglobulins (specific antibodies) are widely reported to be antimicrobial salivary proteins, with special emphasis on the first four proteins $(2,8,9,19)$. These proteins can influence the development of dental biofilms, which inhibit mutans streptococci adherence (4) and modulate planktonic bacterial aggregation to the biofilm $(5,20)$. Other studies show antiviral $(21,22)$ and antifungal effects $(23,24)$. These findings can provide knowledge to further elucidate the role of these proteins in the pathogenesis of dental caries (25).

This information was used with the purpose of evaluating a possible association between caries experience and caries activity using profiles of salivary protein expression, specifically lysozyme and lactoferrin, in the saliva samples of students both with and without dental caries. Lysozyme is produced by the major and minor salivary glands, as well as by the gingival crevice and leukocytes, whereas lactoferrin is only produced by the major and minor salivary glands (18). Total saliva samples were used in the present research, including saliva from the parotid and submandibular glands.

Restored teeth without caries were included in the cariesinactive group. In the case of caries-evolution (active caries), we proposed that a larger number of cariogenic microorganisms that metabolize carbohydrates would be present in the active caries group than in the cariesinactive group, and possibly, there would also be a larger concentration of salivary proteins, which act as antimicrobial agents. Therefore, caries-active students composed Group A while caries-inactive students composed Group B. Of the 80 total children, $58.8 \%$ were caries-inactive (Group B).

Children also were divided into Groups 1 and 2. Group 1 comprised students with caries experience, including those with restored teeth. These children did not have any active caries, though they already had previous disease experiences that were repaired by restorations. Group 2 included students whose teeth had no caries experience and only healthy teeth. Of the 80 children, $63.3 \%$ had present or previous caries experience (Group 1).

The statistical results showed that lysozyme was not associated or correlated with the DMFT index. Lysozyme exerts a considerable antimicrobial effect, higher than that of LF. There was a larger concentration of lysozyme in the saliva (concentration about 41.74 to $93.86 \mathrm{mg} / \mathrm{L}$ ) than lactoferrin, which was present in concentrations ranging from 2.95 to $10.49 \mathrm{mg} / \mathrm{L}$. Only three children $(3.8 \%)$ from this study failed to express lysozyme in their saliva, though there were no statistical differences in the concentrations between children with or without caries.

As shown in Table 1, the DMFT index and its component values decreased as the lysozyme concentrations increased. Thus, they are inversely proportional, which indicates that lysozyme also provides protective and antimicrobial effects. There were no statistical differences between groups with or without caries. However, the high concentration of lysozyme inside the oral cavity suggests that it should have an important role in dental caries prevention. Mass et al. (6) observed an association between lysozyme concentration and dental caries, and we also found a slight association in the present study.

Another point regarding lysozyme is its major expression in the gels compared to lactoferrin. Almost all of the subjects in this study presented LZ in their saliva. Therefore, during 
statistical testing, a decision was made to categorize LZ concentrations into three intervals (Tables 2 and 3). The categories were based on the number of children allocated inside three intervals. As reported by Banderas-Tarabay et al. (10), the analysis of salivary molecules is normally reported as present or absent. The presence or absence of lysozyme was tested as well as three categories. In both conditions, no significant association between lysozyme and DMFT was detected.

A demarcation of the three bands of the LZ concentrations was established by population distribution, based on the results from the polyacrylamide gel electrophoresis (SDS-PAGE). During the evaluation of the results, all of the children presented different concentrations of LZ. The value was lower than $81.55 \mathrm{mg} / \mathrm{mL}$ in 24 students, between $81.56 \mathrm{mg} / \mathrm{mL}$ and $91.55 \mathrm{mg} / \mathrm{mL}$ in 28 students and higher than $91.56 \mathrm{mg} / \mathrm{mL}$ in 28 students. The three groups each contained approximately the same numbers of children. A demarcation in the bands or groupings of LZ concentrations was not found in any other publication. Thus, the present study determined the concentrations of the salivary lysozyme as high, moderate and low.

Lactoferrin was more significantly expressed in the presence of restored teeth, a component of the DMFT index, according to the Kruskall-Wallis test (Table 3). The Pearson test showed a significant correlation between LF and the DMFT index, as well as between LF and restored teeth (Table 4). The values of the coefficient test were not very high, however. Vitorino et al. (13) and Azevedo et al. (12) also observed a relationship between LF expression and the DMFT index. Azevedo et al. (12) found a relationship between caries risk/activity and polymorphism of the lactoferrin gene. Sikorska, MielnikBlaszczak, Kapec (11) showed a significant relationship between LF levels (by ELISA method) and the DMFT index in 83 15-year-old children, which are results similar to those in the present study, despite the use of different methodologies.

Of note is the finding that lactoferrin was the only salivary protein associated with the DMFT index. The presence of lactoferrin seems to be associated with dental caries occurrence (11-13), which can contribute to an improved understanding of the etiology, development and prevention of dental disease.

\section{Conclusions}

High levels of the salivary protein lysozyme were associated with high DMFT index values, although these results were not statistically significant. Forty-five percent of the students did not express the lactoferrin protein in their saliva when tested with polyacrylamide gel electrophoresis. However, when the protein was present, it was correlated to a high DMFT index and to the number of restored teeth.

Salivary proteins constitute an important defense mechanism as nonspecific antimicrobial agents; hence, their quantification and correlation to dental caries can contribute to future analyses of the factors of dental caries risk.

\section{Acknowledgments}

This study received financial support from North of Paraná University (UNOPAR, Universidade Norte do Paraná) and the National Foundation for the Development of Privatelyheld Institutions of Higher Education (FUNADESP, Fundação Nacional de Desenvolvimento do Ensino Superior Particular).

\section{References}

1. Leone CW, Oppenheim FG. Physical and chemical aspects of saliva as indicators of risk for dental caries in humans. J Dent Educ 2001;65:1054-62.

2. Van Nieuw Amerongen A, Bolscher JG, Veerman EC. Salivary proteins: protective and diagnostic value in cariology? Caries Res 2004;38:247-53.

3. Kidd EA, Fejerskov $O$. What constitutes dental caries? Histopathology of carious enamel and dentin related to the action of cariogenic biofilms. J Dent Res 2004;83:C35-8

4. Oho T, Mitoma M, Koga T. Functional domain of bovine milk lactoferrin which inhibits the adherence of Streptococcus mutans cells to a salivary film. Infect Immun 2002;70:5279-82.

5. Berlutti F, Ajello M, Bosso P, Morea C, Petrucca A, Antonini G et al. Both lactoferrin and iron influence aggregation and biofilm formation in Streptococcus mutans. Biometals 2004; 17:271-8.

6. Mass E, Gadoth N, Harell D, Wolff A. Can salivary composition and high flow rate explain the low caries rate in children with familial dysautonomia? Pediatr Dent 2002;24:581-6.

7. Loesche WJ. Role of Streptococcus mutans in human dental decay. Microbiol Rev 1986;50:353-80.
8. Arnold RR, Brewen M, Gauthier JJ. Bactericidal activity of human lactoferrin: sensitivity of a variety of microorganisms. Infect Immun 1980;28:893-8.

9. Lassiter MO, Newsome AL, Sams LD, Arnold RR. Characterization of lactoferrin interaction with Streptococcus mutans. J Dent Res 1987;66:480-5

10. Banderas-Tarabay JA, Zacarías-D'Oleire IG, Garduño-Estrada R, Aceves-Luna E, González-Begné M. Electrophoretic analysis of whole saliva and prevalence of dental caries. A study in Mexican dental students. Arch Med Res 2002;33:499-505.

11. Sikorska MH, Mielnik-Blaszczak M, Kapec E. The relationship between the levels of SigA, lactoferrin and alpha (1) proteinase inhibitor in saliva and permanent dentition caries in 15-year-olds. Oral Microbiol Immunol 2002;17:272-6.

12. Azevedo LF, Pecharki GD, Brancher JA, Cordeiro CA Jr, Medeiros $K G$, Antunes $A A$ et al. Analysis of the association between lactotransferrin (LTF) gene polymorphism and dental caries. J Appl Oral Sci 2010;18:166-70.

13. Vitorino R, Guedes SM, Ferreira R, Lobo MJ, Duarte J, FerrerCorreia $\mathrm{AJ}$ et al. Two-dimensional electrophoresis study of in vitro pellicle formation and dental caries susceptibility. Eur J Oral Sci 2006;1 14:147-53. 
14. Westermeier R. Electrophoresis in practice: a guide to methods and applications of DNA and protein separations. $2^{\text {nd }}$ ed. Weinheim: Wiley-VCH; 1997.

15. Schwartz SS, Zhu WX, Sreebnyl LM. Sodium dodecyl sulphatepolyacrylamide gel electrophoresis of human whole saliva. Arch Oral Biol 1995;40:949-58.

16. World Health Organization. Oral health. [acessed 2009 Mar 15]. Available from: http://www.who.int/oral_health/en/

17. Laemmli UK. Cleavage of structural proteins during the assembly of the head bacteriaophage T4. Nature 1970;227:680-5.

18. Arnold RR, Cole MF, McGhee JR. A bactericidal effect for human lactoferrin. Science 1977;197:263-5.

19. Jenssen H, Hancock RE. Antimicrobial properties of lactoferrin. Biochimie 2009;91:19-29.

20. Singh PK. Iron sequestration by human lactoferrin stimulates Paeruginosa surface motility and blocks biofilm formation. Biometals 2004; 17:267-70.
21. Müller F, Holberg-Petersen M, Rollag H, Degre M, Brandtzaeg $P$, Froland SS. Nonspecific oral immunity in individuals with HIV infection. J Acquir Immune Defic Syndr 1992;5:46-51.

22. van der Strate BW, Beliaars L, Molema G, Harmsen MC, Meijer DK. Antiviral activities of lactoferrin. Antiviral Res 2001;52: 225-39.

23. Samaranayake YH, Samaranayake LP, Pow EH, Beena VT, Yeung KW. Antifungical effects of lysozyme and lactoferrin against genetically similar, sequential Candida albicans isolates from a human immunodeficiency virus-infected southern Chinese cohort. J Clin Microbiol 2001;39:3296-302.

24. Lupetti A, Annema PA, Welling MM, Ballering-Dogterom H, Brouwer CPJM, Senesi $S$ et al. Synergist activity of the N-terminal peptide of human lactoferrin and fluconazole against Candida species. Antimicrob Agents Chemother 2003;47:262-7.

25. Orsi N. The antimicrobial activity of lactoferrin: current status and perspectives. Biometals 2004;17:189-96. 